Departamento de Historia Universidad de Santiago de Chile

Revista de Historia Social

y de las Mentalidades

Volumen 23, $\mathrm{N}^{\circ} 1,2019: 105-136$

Issn: 0717-5248

Issn On Line: 0719-4749

\title{
OBRERISMO Y ANTIGUERRERISMO, OTROS NEXOS ENTRE INTELECTUALES, ARTISTAS Y PARTIDOS COMUNISTAS EN EL CONO SUR EN LA DÉCADA DE 1930*
}

\author{
OBRERISMO AND ANTIGUERRERISMO, WAYS OF CONNECTION BETWEEN \\ INTELLECTUALS, ARTISTS AND COMMUNIST PARTIES IN THE SOUTH CONE, \\ 1930 DECADE
}

\author{
DRA. LAURA PRADO ACOSTA** \\ Universidad Nacional de Quilmes / Universidad Nacional Arturo Jauretche \\ Argentina \\ Email: lauriprado@hotmail.com \\ Id-ORCID: 0000-0001-9493-0783
}

\begin{abstract}
RESUMEN
Los estudios sobre la relación entre intelectuales, artistas y partidos comunistas se han centrado, en general, en el período antifascista, marcado por el

VII Congreso de la Internacional Comunista en 1935. En este artículo se indaga, en cambio, en vínculos establecidos en una etapa previa, generados en torno a una sensibilidad obrerista y al rechazo a la Guerra del Chaco (1932-1935). Este replanteo en la periodización se realiza a partir de la reconstrucción de tres escenarios, en Uruguay, Argentina y Chile, se muestran los múltiples proyectos, tensiones y
\end{abstract}

\begin{abstract}
The studies about the relationship between intellectuals, artists and communist parties usually focus in the antifascist times, shaped by the VII Congress of the Comintern. This article inquires in previous connections, generated by a pro-worker sensibility, and by the reject to the Guerra del Chaco (1932-1935). The change in the period is done analyzing three stages, in Uruguay, Argentina y Chile, it's shown the multiple projects, tensions and strategies followed by the communists intelectualls and artists.
\end{abstract}

* $\quad$ Recibido: 24 de septiembre de 2018; Aceptado: 2 de noviembre de 2018.

** Artículo científico. Este trabajo es parte de la investigación doctoral en ciencias sociales de la Universidad de Buenos Aires, financiada por CONICET y enmarcada en el Centro de Historia Intelectual de la Universidad Nacional de Quilmes. 
estrategias por las que transitaron los intelectuales y artistas comunistas en el Cono Sur.

Palabras clave: Comunismo; intelectuales; artistas; obrerismo; antiguerrerismo
Keywords: Communism; Intellectuals; Artists; Obrerismo; Antiguerrerismo

Cómo citar: Prado Acosta, Laura. "Obrerismo y antiguerrerismo, otros nexos entre intelectuales, artistas y partidos comunistas en el Cono Sur en la década de 1930". Revista Historia Social y de las Mentalidades, 23(1), 105-136. https://doi.org/10.35588/rhsm.v23i1.4115

\section{INTRODUCCIÓN: INTELECTUALES OBRERISTAS}

Los partidos miembros de la tercera Internacional Comunista se conformaron en torno a la idea de que representaban los intereses de la clase obrera adoptando la forma de una vanguardia del proletariado. La tensión respecto de quiénes eran aptos para integrar esa vanguardia fue un conflicto constante en el desarrollo de los comunismos en todo el mundo. Una de las dificultades residía en dilucidar si los afiliados que no pertenecían a la clase obrera habían efectivamente abandonado su ideología de origen "burgués" para luchar por los intereses proletarios. En particular, fue intrincada la relación de los partidos con los intelectuales y artistas, en general caracterizados como parte de una "pequeña-burguesía". Como es sabido, los orígenes de tal vínculo pueden rastrearse ya en el Manifiesto del Partido Comunista, donde Karl Marx sostuvo que al tiempo que la lucha de clases se acercara a su desenlace habría un sector de "ideólogos burgueses" que, en su comprensión de la teoría del conjunto del movimiento histórico, se unirían al movimiento político revolucionario cuyo sujeto principal era el proletariado (101).

Las investigaciones que indagan el vínculo entre intelectuales y comunismo partidario de matriz soviética, como las de Tony Judt (2011), Gertje Utley (2000) y Jeannine Verdès (1983) consideran, en general, que el VII Congreso de 1935 generó el acercamiento entre las "capas pequeño burguesas de las ciudades", entre ellas los intelectuales, a la vez que propició un acercamiento con las socialdemocracias debido a que dio importancia a la lucha ideológica contra el fascismo. Como corolario, el período de 'frentes populares antifascistas' suele contrastarse con el denominado 'tercer período' (entre los años 1928 y 1935), descripto como un momento estrictamente 'obrerista', tanto porque predominó la consigna de 'clase contra clase' como por la exitosa inserción de los PPCC en los ámbitos sindicales. En la perspectiva de gran parte de la historiografía, este 'tercer período' resultaría un momento "anti-intelectualista" debido a su obrerismo. 
En este artículo se analizan episodios que permiten relativizar y problematizar esa contraposición entre el obrerismo y la participación de los intelectuales en el partido. Se propone un análisis en tres escenarios en Sudamérica en los que esa relación se tornó visible, demostrando que, es preciso replantear las periodizaciones tradicionales y, junto con ellas, las aseveraciones que adjudican al VII Congreso el impulso que motorizó el ingreso de los intelectuales al comunismo. En el primer apartado, se estudia uno de los modos en que la figura del intelectual se incorporó al discurso obrerista del sindicalismo ligado a los PPCC. En especial, se indaga cómo fue incorporándose la figura del intelectual en la publicación sindical El trabajador Latino Americano, y cómo las convocatorias antiguerreras afianzaron ese vínculo en ocasión del Congreso Antiguerrero Latino Americano en Montevideo en 1933.

El segundo apartado se centra en la Argentina, y analiza las formas en que intelectuales y artistas buscaron "obrerizarse", por un lado, formando agrupaciones gremiales propias, y, por otro, solidarizándose con las causas proletarias: diferentes modos organizacionales encarnaron concepciones diversas sobre la tarea del intelectual como trabajador. En este segundo escenario se indagan la tensión y las articulaciones entre las organizaciones de tipo sindical y unionista, y las agrupaciones intelectuales antiguerreras, antifascistas y de defensa de la cultura.

El tercer apartado se focaliza en las disputas entre agrupaciones de intelectuales comunistas en Chile. Allí, las diferentes formas de concebir el rol del intelectual comunista se exacerbaron al tornarse públicas y personales. Tres exponentes principales de la poesía chilena, Vicente Huidobro, Pablo de Rokha y Pablo Neruda, conformaron agrupaciones ligadas al espacio cultural comunista desde donde combatieron por el espacio simbólico y por la definición del vínculo entre el intelectual-artista, el mundo obrero y la posición en el ámbito cultural partidario. De este modo, a partir de episodios en Uruguay, Argentina y Chile se observan diferentes ángulos de la relación entre obreros, intelectuales, artistas y partido.

\section{PRIMER ESCENARIO: SINDICATOS E INTELECTUALES COMUNISTAS EN URUGUAY}

En mayo de 1929 se realizó en Montevideo la Conferencia Sindical Latino Americana y se constituyó la Confederación Sindical Latino Americana (CSLA); organización de alcance regional en la que los comunistas buscaban difundir el contenido programático de su línea política y articularlo con una creciente presencia en los ámbitos sindicales nacionales. La confederación generó un órgano de prensa oficial, la revista El trabajador Latino Americano, 
con un comité de redacción y una administración situados en Montevideo, que se mantuvieron anónimos. La revista, cuya publicación se inició en septiembre de 1928 y duró hasta febrero de 1933, resulta clave para analizar el 'obrerismo' del período 'clase contra clase' en el Cono Sur, y los cambios que se produjeron en el espacio ocupado por el intelectual en un ámbito obrero-sindical. Debe tenerse en cuenta, que desde 1930 la ciudad de Montevideo se encontró en el centro de la escena comunista sudamericana, al menos en tanto que allí se situó la sede del Secretariado Sudamericano de la Internacional Comunista cuando, a raíz del golpe de estado argentino, debió ser trasladada desde Buenos Aires.

Las principales líneas tácticas y políticas de los comunistas adheridos al Secretariado Sudamericano provenían del período previo a los golpes de estado y las crisis de 1930. Las resoluciones de la Conferencia Sindical de Montevideo, y también las de la Conferencia de los Partidos Comunistas Latinoamericanos, realizada en Buenos Aires en junio de 1929, estuvieron en consonancia con las resoluciones del VIII Congreso del PC argentino de 1928, en el que se delineó una definición de la época y del modo que debía adoptar la revolución en la región. En esas reuniones se afirmó que estaban transitando el tercer período, definido por Victorio Codovilla como un momento histórico de "agravación de las contradicciones capitalistas, de los conflictos inter-imperialistas, de las crisis revolucionarias con ritmo acelerado, de las guerras y de las luchas revolucionarias. En una palabra: es el período agónico del capitalismo" (Codovilla). En ese contexto, los principales temas fueron: el "peligro de la guerra"; la caracterización de la revolución, que debía ser democrático-burguesa "agraria y antiimperialista" basada en una unión obrero-campesina debido a la condición semi-colonial de la región, la cuestión indígena, con la resolución del apoyo a la autodeterminación de las nacionalidades, y, por último, el trabajo sindical, espacio estratégicamente central para los partidos comunistas.

Hernán Camarero (2011) ha demostrado que el ámbito sindical era esencial para los objetivos partidarios. Si bien, la participación sindical y la membresía partidaria mantuvieron canales paralelos, se intentó establecer vasos comunicantes, como fue la CSLA, pero no pudo evitarse la proliferación de debates. Éstos se centraron en las formas de organizarse y en los modos en que debía vincularse el partido con los sindicatos no comunistas. En las páginas de El trabajador Latino Americano (ETLA) resalta como referente sobre los "problemas de organización y estructura sindical" Alejandro Losovsky, "Secretario General de la Internacional Sindical Roja, miembro del Presidium del Consejo Central de los sindicatos de la URSS, del Presidium de la Internacional Comunista, miembro de la Academia Comunista, miembro del Comité Central Ejecutivo de la URSS" ("Figuras del movimiento obrero" s/p). Uno de los 
planteos principales de Losovsky fue que los "sindicatos por oficio" eran un instrumento de lucha viejo, aristocratizante e inadecuado para el momento de concentración que estaba viviendo el capitalismo, del mismo modo en que las empresas estaban en proceso de concentrarse, los sindicatos debían seguir esa tendencia y unificarse en "sindicatos de industria y producción" ("Origen y desarrollo de los sindicatos de oficio" s/p).

Por su parte, Victorio Codovilla, figura central del Secretariado Sudamericano, se encargó de compartir las tesis sobre el trabajo sindical en un Comité Central ampliado en la Argentina. Se refirió a dos posibilidades de acción. En primer lugar, la creación y organización de Comités de fábrica, empresa o estancia: allí donde los trabajadores estuvieran desorganizados, el comunista debía reunirlos en conferencias y constituir Comités de huelgas para lanzar la lucha: "esa es la verdadera forma de realizar el frente único por la base", afirmó (Codovilla 68). Y agregó un segundo modo de acción: en los casos en que se considerara necesaria la unidad sindical, los afiliados comunistas podían integrarse a sindicatos ya existentes con el fin de evitar el aislamiento (68). Ambas posibilidades debían evaluarse con el fin de insertarse a las luchas que se desarrollaban en un contexto regional en el que el movimiento obrero estaba en expansión, a la vez que era fuertemente reprimido por la mayoría de los gobiernos de Latinoamérica.

Para Codovilla la alianza revolucionaria era obrero-campesina, y quienes quedaran fuera de esa definición eran "colaboradores" o "aliados" que aportaban diferentes recursos materiales y simbólicos para su triunfo. Aun así, como se desarrolla en profundidad en el próximo apartado, a inicios de los años treinta, dentro de estos sectores que no lograban definirse, estrictamente, como obreros o campesinos, también se buscó formar organizaciones gremiales propias, en particular, algunos grupos de escritores y artistas plásticos intentaron agruparse a la manera de los sindicatos obreros.

Para estos escritores y artistas plásticos que buscaron agremiarse, resultaron clave algunas líneas directrices: las mencionadas sobre las agrupaciones por oficio, provenientes del mundo soviético a través de la figura de Losovsky; las pautas planteadas por los dirigentes partidarios locales y del SSA como Codovilla; y también, las experiencias de quienes habían articulado, en Latinoamérica, el ámbito sindical, el partidario y los espacios artísticos e intelectuales. Entre estos últimos, se destacan los recorridos de David Alfaro Siqueiros, Vicente Lombardo Toledano y José Carlos Mariátegui, quienes encarnaron diferentes modos de concebir la relación entre intelectuales y mundo obrero en la región, durante el tercer período, cuyos itinerarios figuran también en la revista montevideana ETLA. 
Siqueiros ingresó al comunismo desde un espacio gremial que agrupaba a los trabajadores de los murales en México, fue secretario general del Sindicato de Obreros Técnicos, Pintores y Escultores (SOTPE). Progresivamente, Siqueiros abandonó ese espacio para integrarse de lleno a las tareas partidarias: formó parte del Comité Ejecutivo del PC mexicano, presidió la Liga Antiimperialista de las Américas, dirigió la Liga de Comunidades Agrarias de Jalisco y la Federación Minera de Jalisco y en 1928 viajó a Moscú para participar en el IV Congreso de la Internacional Sindical Roja. Antes de ser expulsado del PC mexicano en 1930 (luego fue reincorporado), Siqueiros integró el Comité Ejecutivo y el Secretariado de la Conferencia Sindical de Montevideo en 1929, allí afirmó que, si bien todo lo sostenido por Losovsky era cierto, la tarea de la Conferencia era estudiar y explicar la situación concreta de cada uno de los países y encontrar una táctica justa para la lucha local, para lo cual presentó un informe en el que describió las características de las organizaciones sindicales mexicanas. Siqueiros brindó su perspectiva sobre las posibilidades de acercamiento a sectores de la intelectualidad "semi proletaria" como "aliados temporales":

"En la lucha contra un enemigo tan peligroso como el imperialismo, es menester aprovechar todas las fuerzas que en uno u otro grado están dispuestas a luchar contra de él, aunque sean aliados auxiliares y temporales. Entre estos aliados temporales se puede mencionar a la pequeña burguesía de las ciudades y de los intelectuales semi proletarizados [sic]. Ellos están por una parte bajo la presión de las masas trabajadoras a las cuales los une cierta similitud de su situación social, por ser explotados por el gran capital, y por otra parte, ya sea por su procedencia, su educación o ambiente y en parte por sus intereses, están ligados con la burguesía agraria, comercial e industrial..." (Siqueiros 210-220).

Siqueiros recogía un debate sobre la proletarización de los intelectuales que en México había tenido gran alcance, uno de cuyos referentes fue Vicente Lombardo Toledano, quien, en los años veinte, fue miembro del Partido Laborista y, luego de su distanciamiento con tal partido, se incorporó a la órbita del PC mexicano y estuvo en vinculación con el mundo soviético, tal como lo han señalado Jeifets (2015) y Àlvarez (1995). En 1927, mientras Lombardo Toledano era Secretario de Educación de la Confederación Regional Obrera Mexicana (CROM) y Secretario General de la Federación Nacional de Maestros de México, se aprobó un estatuto promovido por él sobre los derechos de los "trabajadores intelectuales". Allí se reconstruyó la historia 
de las "desconfianzas" que los obreros y campesinos profesaban hacia los intelectuales, historia que buscaba superarse con la unión entre trabajadores manuales y trabajadores intelectuales. Ésta se basaría en una confluencia de intereses, consolidada en el estatuto sindical, que les brindaba a ambos "los mismos derechos y obligaciones, dentro de las organizaciones sindicales obreras y respecto del Estado" (Lombardo 27).

Mientras Lombardo Toledano consideraba posible una suerte de asimilación entre trabajadores intelectuales y manuales, la postura de Siqueiros fue más compleja y puso en cuestión la identificación entre ambos sectores. Luego de dejar su puesto de secretario general del SOTPE, Siqueiros fue convocado por los gobernantes de Jalisco, Guadalupe Zuno y Margarito Ramírez, desde allí comenzó a representar a los trabajadores mineros, alejándose por un tiempo del ámbito artístico. Su labor unificó la representación sindical minera con la lucha política de Jalisco contra el gobierno nacional de Elías Calles, crecientemente represivo en particular con los comunistas. Con el fin de representar a los mineros, Siqueiros afirmó que se había unido a ellos, con el rol de organizador de tareas de "organizador y agitador" para ese gremio, según lo señalado por Jaime Tamayo (1981).

Las diferentes maneras de concebir la relación obrero-intelectual durante el "tercer período" convivieron en tensión, estructuradas en torno a la interioridad y exterioridad del intelectual respecto de la clase obrera. Una manera consideró al intelectual como un trabajador más, el mismo proletarizado debido a su condición económica y social, y por lo tanto sindicalizable: este fue el caso de Lombardo Toledano. Otra, entendió que eran espacios que se excluían mutuamente, y que debía desprenderse de la condición de intelectual para actuar de lleno en la esfera obrera, tal como se lo propuso Siqueiros en este contexto. Una tercera forma se enfocó en que el intelectual pusiera su inteligencia al servicio de la causa proletaria, como un colaborador que conservaba su exterioridad en tanto que no era él mismo un trabajador sino un intelectual que "se brindaba" al proletariado. Este fue el modo en que el ámbito sindical de la CSLA se relacionó con Mariátegui.

José Carlos Mariátegui fue considerado un "intelectual proletario" por la revista sindical ETLA (Mariátegui, "El problema del indio" s/p). Allí se publicaron varios de sus textos, entre ellos los que fueron leídos en la conferencia sindical de 1929 acompañados de su fotografía con el epígrafe: "intelectual proletario peruano autor de la presente tesis" (Mariátegui, "El problema indígena" s/p). Ante la noticia del encarcelamiento de Mariátegui por parte del gobierno de Leguía, en Perú, y del saqueo de la redacción de Amauta, ETLA denunció: 
"El escritor revolucionario Mariátegui, tan conocido por los lectores del T. L. A. por sus frecuentes colaboraciones. Los compañeros de Lima nos escriben cartas desesperadas donde nos dicen que Mariátegui arrestado corre inminente peligro de morir debido a su salud quebrantada y a los vejámenes físicos y morales que le imponen los verdugos policiales" ("El escritor revolucionario" s/p).

Al brindarse y sacrificarse por completo a la causa proletaria, Mariátegui se hacía merecedor de la condición de "proletario" y de "revolucionario". Como "teórico" del problema indígena, entre otros tópicos, su función fue proporcionar herramientas analíticas al movimiento sindical. Aun cuando sus aportes fueron premiados por el ámbito sindical comunista con los reconocimientos ya mencionados, Mariátegui no era un "trabajador intelectual" que pudiera sindicalizarse por su actividad u oficio, sino un intelectual que se tornaba "revolucionario" debido a la profundidad de su compromiso.

\subsection{La atracción del antiguerrerismo en el contexto de la Guerra del Chaco}

Esta situación de relativa exterioridad de los intelectuales respecto de la clase y del partido (más allá de la valoración positiva a Mariátegui) comenzó a transformarse en los primeros años de la década del treinta, cuando cobró fuerza el problema de la guerra. Exacerbado con el estallido de una guerra sudamericana, la Guerra del Chaco (1932-1935), el tópico antiguerrero multiplicó y consolidó la presencia y las menciones de los intelectuales y artistas dentro de los ámbitos comunistas de la región, incluidas sus publicaciones sindicales.

A partir de esta guerra y con la organización del Congreso Antiguerrero Latino Americano de Montevideo en 1933, los llamamientos antes restringidos a obreros y campesinos empezaron a incluir, primero en un plano secundario, a los "intelectuales antiimperialistas" y a los "intelectuales revolucionarios"; y luego, en el último número de la revista ETLA, tomaron un espacio más destacado al publicarse, a doble página, un "Llamado de los intelectuales argentinos a los intelectuales Latino Americanos" en el que se los invitaba a participar en el Congreso de Montevideo ("Llamado de los intelectuales argentino" s/p). Esta convocatoria, en la que conviven afiliados partidarios con compañeros de ruta del comunismo argentino, revela aspectos poco indagados sobre la relación del comunismo sudamericano con los intelectuales durante el período "clase contra clase". El "llamamiento" pone en evidencia que la mayoría de los intelectuales argentinos filo-comunistas (Cayetano Córdova Iturburu, Álvaro Yunque, Sixto Pondal Ríos, Aníbal Ponce, Héctor Agosti, Facio Hebequer, Roberto Arlt, Elías 
Castelnuovo, León Klimovsky, Rodolfo Ghioldi, Paulino González Alberdi, entre otros), por lo general asociados solo al período de "frente populares antifascistas", ya participaban públicamente de espacios ligados al comunismo antes del VII Congreso de la IC de 1935 y lo hacían interpelados por una guerra ocurrida en la región.

El tópico antiguerrero resultó la llave que integró a la intelectualidad como grupo al mundo comunista sudamericano. Con el inicio de la guerra entre Paraguay y Bolivia, la presencia de artistas e intelectuales se sumó a la de las figuras sindicales y partidarias cuya oposición a las guerras "interimperialistas" había comenzado mucho antes ("Las sesiones de la Conferencia Sindical Anti-Guerrera" s/p) ${ }^{1}$. Debe destacarse que no solo los intelectuales argentinos adhirieron con su "llamamiento" colectivo, también se publicó al respecto un "Manifiesto de los intelectuales uruguayos" ("Frente al problema de la guerra" $\mathrm{s} / \mathrm{p}$ ), y adhirieron importantes figuras intelectuales y artísticas de Chile, entre ellos, como veremos, el poeta Pablo de Rokha, Gerardo Seguel, Marta Vergara y Enrique Mosella ("Chile frente al Congreso de Montevideo" s/p); también artistas e intelectuales brasileños, como Tarsila de Amaral.

Debe agregarse que, si bien el antiguerrerismo en el Cono Sur tomó fuerza a raíz de un enfrentamiento bélico local, el tipo de organización antiguerrerista tuvo un origen europeo, ligado al Congreso Mundial Antiguerrero de Ámsterdam en 1932. En realidad, el problema de la guerra fue un eje central en la historia del comunismo soviético desde sus orígenes. Como es sabido, en torno a la Gran Guerra se estructuraron las diferencias de Lenin con la II Internacional. Así, la paz de Brest Litovsk fue uno de los logros principales de la Revolución de Octubre y desde entonces la oposición a la guerra fue parte del repertorio de consignas de los PPCC.

Antes del inicio de la Guerra del Chaco, la revista ETLA cubrió el Congreso Mundial contra la Guerra de Ámsterdam (1932), ilustrado con fotografías de Henri Barbusse y Romain Rolland. Allí resultó fundamental la figura del "compañero de ruta" representada por Rolland, que permitía ampliar la convocatoria; y que, al mismo tiempo, expresó una modalidad de relación entre

1 En febrero de 1929, se convocó a una Conferencia Sindical Sud Americana Contra la Guerra, en la que participaron el Centro Obrero Regional de Paraguay, la Unión Obrera del Paraguay, la Confederación Boliviana del Trabajo, así como la Unión Sindical Argentina (USA) y delegaciones de Brasil. También en 1929, en el manifiesto de la CSLA una sus principales proclames fue: "¡Contra los peligros de las guerras Latino Americanas provocadas por el imperialismo angloamericano, en complicidad con las burguesías nacionales!" en "Las sesiones de la Conferencia Sindical Anti-Guerrera". 
el intelectual y los obreros en la coyuntura guerrera. En un recuadro citado en la revista sindical montevideana, se reprodujo un fragmento de su intervención en el Congreso: "No tenemos que hacernos ilusiones. No serán algunos intelectuales los que detendrán la guerra sino la fuerza organizada del pueblo trabajador de las fábricas y de los transportes" (ETLA 51-2) .

Esta afirmación centrada en el rol preponderante de los trabajadores no reñía con la estrategia de que la convocatoria estuviera a cargo de intelectuales y artistas, junto a federaciones obreras y dirigencia partidaria. De ese modo, conjunto, se presentaron las figuras y organizaciones participantes del Congreso de Montevideo de 1933 que fue convocado un conglomerado formado por la Federación Obrera de Chile, la Confederación General del Trabajo de Perú, la Confederación General del Trabajo del Uruguay, la Confederación General del Trabajo brasileña, la Confederación Sindical Unitaria de México, el Comité Unidad Sindical Clasista de Argentina, y, junto a esas organizaciones, firmaron los dirigentes partidarios comunistas Oscar Creydt (de Paraguay); Luiz Carlos Prestes, Octavio Brandao, Fernando Lacerda (de Brasil); Eudocio Ravinez, Julio Portocarrero, Quispe Quispe (de Perú); Elías Lafertte, Contreras Labarca, "el sargento" Pacheco (de Chile); Paulina Medeiros (del Uruguay); Aníbal Ponce, Emilio Troise, Córdova Iturburu, Elías Castelnuovo, Facio Hebecquer, González Alberdi y Rodolfo Ghioldi (de Argentina) ("Comunicado oficial del Comité organizador" s/p). En esta lista, y en este escenario del Congreso de Montevideo en 1933, se expresó una forma de convivencia entre confederaciones obreras, dirigencias partidarias e intelectuales. Como se verá, esa interacción buscó afianzarse en múltiples proyectos asociacionistas.

\section{SEGUNDO ESCENARIO: AGRUPACIONES DE ESCRITORES, ARTISTAS E INTELECTUALES EN LAARGENTINA}

Entre 1932 y 1934 se formaron en el Cono Sur la Asociación de Escritores y Artistas Revolucionarios de Chile; la Confederación de Trabajadores Intelectuales del Uruguay; la Unión de Escritores y Artistas Revolucionarios, de Rosario; en Buenos Aires, el Sindicato de Artistas Plásticos, el Grupo de del comunismo, no afiliados, que participaron en las publicaciones periódicas y adhirieron con su firma a las proclamas patrocinadas por el comunismo, pero que, por distintos motivos, en especial en países donde los PPCC se encontraban en la ilegalidad, se mantuvieron por fuera de la estructura partidaria. Estas figuras fueron claves en la composición de la cultura comunista en los países en los que el PC no eran gobierno. 
Arquitectos de Izquierda, la Unión de Escritores Proletarios; y en Santa Fe, otra Unión de Escritores Proletarios. A la vez, se realizó el mencionado Congreso Antiguerrero Latino Americano, organizado, entre otros, por el intelectual Aníbal Ponce quien, dos años más tarde, fundó la Asociación de Intelectuales Artistas Periodistas y Escritores (AIAPE), luego replicada en las AIAPE de Montevideo, Asunción del Paraguay y de numerosas ciudades del interior de la Argentina; y que en Chile se vinculó con la Alianza de los Intelectuales por la Defensa de la Cultura ${ }^{3}$.

Estas organizaciones artístico-intelectuales, que estuvieron ligadas a los PPCC, pueden agruparse en dos grandes tendencias: la primera, vinculada a una convocatoria por oficio (escritores, artistas plásticos, músicos, actores, periodistas u otros trabajadores de la cultura); la segunda, a objetivos de "defensa de la cultura", con consignas antiguerreras, antifascistas y una agenda de actividades y definiciones sobre los comportamientos de los intelectuales. El primer grupo suele asociarse al momento partidario de "clase contra clase", y el segundo, al de los "frentes populares antifascistas" iniciado con el VII Congreso de la Internacional Comunista de 1935, esta periodización sugiere una escena de prolijos acatamientos a las resoluciones de la IC. No obstante, al seguir los recorridos de quienes fundaron y fomentaron esas agrupaciones, se advierte una topografía más irregular, en la que se manifestaron estrategias organizacionales diferentes que funcionaron sincrónicamente y sufrieron transformaciones en sus posicionamientos, ligadas además a cambios y pujas de un espacio cultural soviético candente y difícil de decodificar.

Debe señalarse que los grupos de escritores, artistas e intelectuales en el Cono Sur se sintieron interpelados por los llamados de agrupaciones y congresos soviéticos, pero también por aquellos europeos como la Asociación de Escritores y Artistas Revolucionarios (AEAR) sección París, y por los Congresos Antiguerreros de Ámsterdam, y Berlín, por ejemplo. También Estados Unidos generó una fuerte influencia, que ha sido poco abordada por la historiografía, con sus organizaciones de escritores como John Reed Club o la revista New Masses, que se publicitaron en la revista argentina Actualidad, asegurando que "50.000

Sus manifiestos o proclamas se publicaron en las revistas culturales ligadas al comunismo, principalmente en Actualidad y Contra; la Confederación de Trabajadores Intelectuales del Uruguay tuvo su periódico orgánico, Movimiento; la Unión de escritores proletarios de Santa Fe, su periódico Ahora! (con un sólo número). El Congreso Anti-guerrero, publicó el Boletín del Comité Organizador del Congreso Antiguerrero de Latinoamericano. La AIAPE publicó Unidad y Nueva Gaceta; la Alianza de los intelectuales por la defensa de la cultura en Chile, el periódico Aurora de Chile. 
trabajadores intelectuales de América organizados y actuando en organizaciones culturales revolucionarias en todas las secciones del país tienen por vocero a New Masses, revista mensual americana de literatura y arte revolucionario"4. La identificación y referencia a agrupaciones extranjeras sirvió para legitimar las acciones locales, pero no resolvió las búsquedas organizacionales de quienes se consideraban a la vez receptores de esas tendencias mundiales y miembros de un espacio cultural local.

Nos centraremos en este apartado, en la Argentina, donde en mayo de 1932 en la ciudad de Santa Fe se formó una Unión de Escritores Proletarios (UEP), que manifestó responder al llamado del Congreso de Karkoff, que reunió a los escritores soviéticos. ¡Uno de los objetivos de la UEP santafecina fue publicar una revista, llamada Ahora!, donde se informó que se constituían como un "órgano auxiliar del movimiento emancipador del pueblo". La revista tuvo un solo número, en el que se realizaron denuncias sobre el estado de la cultura en Santa Fe, sobre "palizas" recibidas por obreros de la provincia, y sobre las muertes por hambre en el Chaco. Los integrantes de la UEP se definieron por su oposición al "individualismo intelectual", y su adhesión al proletariado.

Un mes después, en junio de 1932, en Buenos Aires, en la revista filo comunista Actualidad, se publicó un anuncio sobre la conformación de otra Unión de Escritores Proletarios en Argentina. En un primer recuadro se informó que estaba por constituirse una UEP que tendría por finalidad, al igual que "las entidades análogas que existen en todos los países del mundo", sostener el principio de la lucha de clases, combatir el imperialismo y defender la Unión Soviética, así como participar en las luchas del proletariado y "preparar el terreno para que a la literatura nacional se le imprima un carácter social definido" ("La Unión de escritores proletarios" s/p). La comisión directiva de esta agrupación porteña de escritores se conformó primero por Elías Castelnuovo y Roberto Arlt; luego, en asamblea, se votó que Castelnuovo fuera secretario; Carlos Moog, prosecretario; Simón Swasky, tesorero; Roberto Arlt, J. Boero, J. Alonso y Bartolomé Bossio, vocales; y León Klimovsy y Osvaldo Dighero, suplentes.

En la primera asamblea de la UEP se votó en favor de realizar una invitación "a todos los escritores proletarios, redactores de periódicos obreros, corresponsales de fábrica, a que envíen colaboraciones a la revista ACTUALIDAD, tratando con preferencia temas gremiales" ("Unión de escritores proletarios" s/p). Los llamados a adhesión se dirigieron, por un lado, a "escritores argentinos", y por otro, a "corresponsales obreros". A estos últimos, se los consideró la base de los

$4 \quad$ Publicidad de New Masses revista de literatura y arte norteamericana, de New York. 
"futuros escritores proletarios (...) vosotros, que tomáis parte directa de la lucha en el campo, en la fábrica, el taller, el transporte, en los movimientos clasistas, esgrimid la pluma, para contribuir en la Argentina al desenvolvimiento de la literatura proletaria" ("De la Unión de escritores proletarios" s/p). Mientras en la URSS se afirmaba que se habían abolido las clases y que todos eran proletarios, incluidos escritores y artistas que eran "trabajadores creadores", en la Argentina, en el manifiesto de la UEP, se mantenía la distinción entre "obreros que escriben" $\mathrm{y}$ "escritores que se unen a la causa proletaria".

Aun cuando la UEP santafecina manifestó que seguía los postulados del Congreso de Karkoff, a fines analíticos, deben señalarse las dificultades contenidas en un traslado de la idea unionista proveniente de la URSS al contexto argentino. Señalar, por ejemplo, en abril de 1932 en la URRS, por medio de un decreto, dejaron de existir la RAPP (sigla en ruso de la Asociación rusa de escritores proletarios) y la AJRR (sigla de la Asociación de artistas de la Rusia revolucionaria), y que con este cambio organizacional comenzó la etapa estaliniana en la cultura soviética, que buscó terminar con las prácticas vanguardistas que intentaban un camino revolucionario en las artes análogo a la revolución política en curso (Groys 7982). Desde entonces, de acuerdo con lo decidido por el Comité Central del PCUS, todos los "trabajadores creadores" debían reunirse en "uniones de creadores", con arreglo al género de actividad, a fin de terminar con los enfrentamientos facciosos, en especial con las rivalidades entre la RAPP y las vanguardias. De acuerdo con Sheila Fitzpatrick, en medio de lo que se consideraba ya una "revolución cumplida", estos cambios organizacionales establecieron un orden en el que las prácticas culturales se sometieron a la dirección partidaria (Fitzpatrick 181-182).

Problemas diferentes afectaban a las agrupaciones de escritores ligadas al comunismo en la Argentina, donde en el año 1933 el gobierno de Agustín Justo creó la Comisión Nacional de Cultura, que buscaba organizar las actividades intelectuales y artísticas en favor de los sectores nacionalistas y católicos que acompañaban al gobierno, según lo ha planteado Leandro Lacquanti (2016). Esta iniciativa estatal procuró establecer una "política cultural nacional" seleccionando y promoviendo a actores afines, por ejemplo, por medio de premios nacionales y becas estímulo. Los sectores liberales, socialistas y comunistas intentaron distanciarse de estas intervenciones nacionalista generando sus propios espacios organizacionales, que evadían la dependencia al financiamiento estatal. Se establecían así dos regiones diferenciables del campo cultural argentino: una ligada al patrocinio estatal, y otra conformada por quienes progresiva y ampliamente se definían como antifascistas.

En este contexto, para los escritores comunistas argentinos, perseguidos y en algunos casos encarcelados por el gobierno, un asunto principal fue el modo en 
se relacionarían con los espacios gremiales de escritores ya existentes, en particular con la Sociedad Argentina de Escritores (SADE). Si bien las UEP se relacionaban con el oficio y proponían afrontar asuntos gremiales, en sus manifiestos las principales reivindicaciones fueron de orden político internacional: la defensa de la Unión Soviética, la lucha contra la guerra imperialista, y la lucha contra el fascismo y el social fascismo ("Unión de escritores proletarios"); no se mencionan en sus proclamas aspectos específicamente laborales de los escritores, en general trabajadores del periodismo, relativos a salarios, horarios, etcétera.

Un estilo diferente al de la UEP adoptó, en 1933, el Sindicato de Artistas Plásticos (SAP), que también dentro de la órbita cultural comunista, buscó asemejarse a los sindicatos obreros por oficio: "defender sus comunes intereses, obtener reivindicaciones y contribuir al mejoramiento del nivel cultural de las grandes masas"("ElSindicatodeArtistasPlásticos"s/p).Lideradopor Luis Falcini, Antonio Sibellino y Lino Spilimbergo, su funcionamiento, según Cristina Rossi, estuvo ligado al llamado que realizó Siqueiros durante su visita a la Argentina. En la revista Actualidad se publicitó la conformación de esta agrupación. Por un lado, se señaló la diferencia respecto de los modelos organizacionales soviéticos: en la URSS no se concebía la existencia de un sindicato que defendiera intereses de una clase contra otra, porque allí existía una sola clase, la proletaria. Por otro lado, se manifestó una desconfianza respecto de esta nueva agrupación: “... los artistas plásticos se consideran miembros de la clase trabajadora, y por lo tanto con ella se solidarizan (...) No confiamos, porque la experiencia así lo aconseja, en el poder revolucionario del arte" ("El Sindicato de Artistas Plásticos"). Para el articulista de Actualidad, que los artistas plásticos se incluyeran en la clase trabajadora resultaba problemático; aun así, el artículo contempló el aspecto positivo de que la formación del Sindicato reflejaba y denunciaba las deficientes condiciones materiales de vida de muchos artistas.

Las iniciativas unionistas y sindicales (UEP, UEAR y SAP) tuvieron una existencia breve en la Argentina, sin acciones significativas más allá de sus manifiestos publicados en periódicos filo-partidarios. En ellas, incluso cuando se manifestaba la voluntad de organizarse "a la manera de los obreros", se mantuvo en el plano discursivo una relativa exterioridad o una distinción entre los intelectuales y los trabajadores: los primeros se solidarizaban y se unían a los segundos, aunque sin integrarse. Sólo el SAP profundizó en la idea de que el artista era un artesano y un trabajador, pero debió lidiar con que su proyecto quedó ligado a la figura de Siqueiros, quien luego de sufrir una expulsión disciplinaria del PC mexicano en 1930 quedó en una situación de incomodidad en los espacios culturales comunistas del Cono Sur. Y también debió competir con otras organizaciones que ya existían y funcionaban con relativo éxito, 
como la Sociedad Argentina de Artistas Plásticos (SAAP), fundada en 1925. La "desconfianza" generada por este emprendimiento se reflejó en una carta del artista Carlos Giambiagini a Sibellino:

"Estoy enterado de la marcha del sindicato. En el fondo es una cooperativa de artesanos. Pienso que fracasará como han fracasado todas (...) Con todo, la tentativa es útil, no son los artistas los que importan para la revolución, sino los obreros auténticos" (Rossi 90).

En suma, los grupos organizados por oficios no lograron consolidarse debido a que no contaron con la adhesión de una cantidad considerable de escritores o artistas plásticos, ni con un apoyo explícito de la dirigencia partidaria comunista local. Se distinguió así la adhesión a las luchas obreras, del intento de plantear al arte como trabajo.

Hasta 1935 no hubo consenso para unificarse en una estructura organizacional. Sólo la figura del intelectual argentino Aníbal Ponce logró ejercer un rol aglutinador cuando fundó la AIAPE, espacio que reunió a los intelectuales afines al comunismo. Ponce contó con apoyo partidario desde su papel organizador en el Congreso Antiguerrero de Montevideo de 1933. Allí, consiguió lo que no pudieron ni la UEP de Arlt y Castelnuovo, ni la SAP de Spilimbergo: obtener el apoyo abierto y continuado de las revistas culturales comunistas y también de las revistas orgánicas del PCA, así como conciliar las firmas de los dirigentes partidarios Ghioldi y González Alberdi con las de compañeros de ruta como Arlt, Hebequer y Castelnuovo. Ponce convocó con criterios "amplios" a participar en los espacios culturales, tales como Congresos, revistas y luego la agrupación AIAPE. El historiador Ricardo Pasolini (2013) ha destacado la importancia del recorrido previo a la fundación en 1935 de la AIAPE; de acuerdo con su análisis, los antecedentes, junto con el vínculo que Ponce estableció con la experiencia organizacional francesa, permiten comprender el éxito de la AIAPE como espacio cultural ligado al comunismo antifascista.

Desde 1930, cuando dictó la conferencia Los deberes de la inteligencia, Ponce sostuvo que los intelectuales debían conseguir su "absoluta autonomía" ligada a su dignidad personal y su conducta, para lo cual debían afrontar sus obligaciones, liberándose de sus egoísmos. Se refirió, entonces, a "las desconfianzas del proletariado hacia los intelectuales —más exageradas que injustas" sosteniendo que la inteligencia era "la levadura indispensable de la revolución" (Ponce 167-76). Desde entonces debatió abiertamente sobre el rol del intelectual en el espacio político de las izquierdas: 
“... algunos elementos destacados de la extrema izquierda vienen moviendo desde hace años la guerra al intelectual y al pensador. El reino de la inteligencia vendría a ser así, por deseos de unos y exigencias de otros, un reino cerrado que se basta a sí mismo. Los ecos de la calle no llegarían hasta él, y su ambiente sereno no se turbaría jamás con los dolores del hombre. Traición, en un caso, ceguera en el otro, no se concibe por nada la abstención. El deseo agudo de tomar en la vida una actitud definida es ya el deber más alto de la hora" (295).

Como lo ha señalado Pasolini (2013), la figura de Ponce podría situarse en un espacio intermedio entre Rolland y Barbusse. Al igual que Rolland, se mantuvo deliberadamente como compañero de ruta del PC argentino y evitó las expresiones abiertamente partidistas, o la defensa de un realismo socialista prescriptivo para los escritores. Por otro lado, al igual que Barbusse, concibió a la URSS como un mundo nuevo al que describió desde una identificación emotiva, y no dudó en apoyar abiertamente los procesos políticos, sociales y culturales que allí estaban ocurriendo. El origen liberal de la formación de Ponce había resultado una ventaja en la estrategia de establecer contactos amplios con el campo cultural.

Debe resaltarse que la disolución de las mencionadas organizaciones proletarias de escritores y artistas, y la progresiva inserción de sus miembros en las organizaciones ya existentes, por más que fueran consideradas burguesas, como la SADE y la SAAP se vio afectada por la adopción por parte del PC argentino, en 1935, de una nueva estrategia respecto al ámbito sindical en general. Luego de considerar que había actuado de manera sectaria, en la III Conferencia Nacional de Avellaneda se resolvió disolver el Comité de Unidad Sindical Clasista (CUSC, confederación comunista) y se aconsejó a los sindicatos y agrupaciones que ingresaran a la Confederación General de los Trabajadores (CGT). Como lo ha estudiado en profundidad Hernán Camarero (2007), el éxito relativo de esta estrategia se pudo observar recién entre 1939 y 1943, cuando los cuadros del PC argentino alcanzaron la dirección de la CGT, junto con los socialistas, consiguieron diecisiete de cuarenta y cinco cargos en su Comité Central Confederal y su vicepresidencia. Asimismo, "dirigieron varios conflictos laborales y consolidaron su liderazgo sobre los principales sindicatos por rama industrial, como el metalúrgico, el textil, el de la construcción, el de la carne y el del vestido" (Camarero 211).

La historiadora Cristina Rossi ha analizado el modo en el que estos cambios afectaron al Sindicato de artistas plásticos: la táctica que se inició durante el Frente Único - y que se afianzó en el período de los Frentes Populares Antifascistas - fue la de unificarse a los espacios gremiales ya existentes. Los 
artistas plásticos comunistas se integraron a la SAAP y lograron, ya en la década del cuarenta, ocupar su presidencia, vicepresidencia y secretaría, como fue el caso de Raúl Soldi, Juan Carlos Castagnino, Enrique Policastro, Antonio Berni, Demetrio Urruchúa y Raúl Lozza.

Por su parte, los escritores se integraron en la SADE. Esta sociedad fue creada en 1928, en ella interactuaron sectores nacionalistas, liberales e izquierdistas; desde 1938 contó con personería jurídica y con un prestigio construido sobre la base de la participación conjunta de escritores de diversas ideologías. Allí, como lo he analizado en otro trabajo (Prado), el escritor comunista Héctor Agosti, además de participar en la comisión directiva, recibió en 1945 el premio "Faja de honor" por su libro Ingenieros, ciudadano de la juventud.

Sin dudas, 1935 fue un año de transformaciones que estuvieron ligados, en parte, al VII Congreso, pero también, por ejemplo, al final de la Guerra del Chaco; a la muerte de Barbusse y a la fundación del Comité de Vigilance des Intellectuels Antifascistes de París, legado francés que fue trasladado por Aníbal Ponce a Buenos Aires y luego a la región a través de la estructura organizacional de la AIAPE (Ponce s/p). La AIAPE, creada ese año, congregó a diferentes oficios y profesiones intelectuales - artistas plásticos, escritores, periodistas, abogados y médicos-. Tal espacio cultural se definió por lo que no era: "ni partido político, ni capilla sectaria, ni tertulia de snobs, ni asociación de revolucionarios" (Ponce). De acuerdo con su fundador, no importaba que los miembros tuvieran afiliaciones partidarias, allí se remitían a denunciar irrupciones fascistas en el campo cultural. Tal como lo ha analizado ya Pasolini, el lema de la "defensa de la cultura" logró un amplio consenso.

Otro escritor comunista de aquella época, Raúl Larra, rememoró los cambios ocurridos en 1935: si en un principio había formado la Agrupación de Jóvenes Escritores Proletarios (AJEP), junto a Alfredo Varela, Emilio Novas y Emilio Saracco, cuando "La palabra 'proletario' irradiaba una atracción singular sobre los jóvenes idealistas de mi generación. Nos queríamos sentir 'proletarios' como una manera de identificarnos revolucionarios" (Larra 9). Luego de 1935 "los vientos del mundo" y "las máscaras del nazismo" fueron los motivos que los llevaron a retirar la "P" de proletarios en la sigla que quedó como AJE: "para abatirlo [al nazismo] se debía ampliar el campo de aliados. La política era eso: el arte de ganar aliados" (10). Los escritores de AJE se incorporaron y colaboraron, como lo hicieron Tuñón, Spilimbergo y Arlt, a la AIAPE, y luego disolvieron su agrupación. A medida que el ideal de un artista proletario fue tornándose un horizonte realizable sólo en la URSS, en la Argentina la táctica fue integrarse y tratar de ganar aliados en los espacios "burgueses" y combatir al fascismo desde la AIAPE. 


\section{TERCER ESCENARIO: "PROLETARIOS", "REVOLUCIONARIOS", "DEFENSORES DE LA CULTURA”, ARTISTAS E INTELECTUALES EN CHILE}

El Congreso Antiguerrero Latino Americano de Montevideo en 1933 tuvo, como se señaló en el primer apartado, una importante acogida en Chile, donde Ricardo E. Lachtman, había presidido el Comité Antiguerrero Nacional y organizado una Conferencia Antiguerrera preparatoria para el Congreso Continental. La revista montevideana El trabajador Latino Americano publicó un recuadro sobre el apoyo de "Chile frente al Congreso Antiguerrero" con las adhesiones de Gerardo Seguel (poeta y profesor), Ricardo A. Lachtam (escritor), Marta Vergara (periodista), Elías Lafferte y José Barrera (Federación Obrera de Chile), Marcos Chamudes y José Vega (Partido Comunista), Pablo de Rokha y Enrique Mosella (Comité Unido de las organizaciones artísticas de Chile) ("Chile frente al Congreso de Montevideo" s/p), entre otras firmas en las que se mezclaban nombres socialistas, comunistas y anarquistas.

La revista Soviet, del Comité Central del PC argentino, resaltó la amplitud de los integrantes chilenos de esa conferencia preparatoria, y señaló, con ironía, que la búsqueda de un frente único había permitido allí la participación de hasta tres partidos socialistas, anarquistas, "e incluso evangelistas". El PC chileno, creado en 1922 bajo el liderazgo de Luis Emilio Recabarren, había logrado desde la conferencia inaugural en Rancagua la adhesión, prácticamente, de todo el socialismo a las condiciones leninistas que los unificó a la tercera Internacional Comunista, según ha señalado el historiador Sergio Grez Toso (2011). Desde entonces, dos improntas marcaron el itinerario del PC chileno y resaltaron su importancia en el concierto de partidos comunistas de la región: por un lado, una composición social fuertemente obrera, ligada a las actividades mineras y salitreras del norte de ese país, y por otro, su gran efectividad para conseguir alianzas y frentes políticos, que se consolidó en la oposición, por ejemplo, a la dictadura ibañista 5 .

Ese entendimiento con fuerzas políticas aliadas y su éxito en conformar un Frente Popular, triunfante en 1938, paradójicamente contrastó con los fuertes enfrentamientos que, dentro del propio espacio cultural comunista chileno, mantuvieron las figuras de artistas intelectuales. En este apartado se siguen los debates producidos entre los poetas Vicente Huidobro, Pablo de Rokha, Gerardo Seguel y Pablo Neruda, y se atiende al uso que estas figuras hicieron de las

5 Por contraste puede señalarse que el PC argentino nació de una confrontación abierta y por momentos violenta con el Partido Socialista. 
agrupaciones artísticas e intelectuales como espacios desde los cuales sostuvieron impugnaciones personales, a la vez que funcionaron como plataformas de sus posicionamientos intelectuales y políticos.

En agosto de 1933 el poeta Vicente Huidobro, como Secretario General de la Asociación de Escritores y Artistas Revolucionarios (AEAR) de Chile, firmó el "Manifiesto de los escritores revolucionarios chilenos" que fue enviado a la revista Contra de Buenos Aires (Huidobro 1933). Allí se denunciaron las persecuciones por parte del nuevo gobierno chileno presidido por Arturo Alessandri (1932-1938), sucesor de Carlos Ibáñez (1927-1931), quien debió abandonar la presidencia y el país en medio de manifestaciones en su contra, que incluyeron un breve interludio revolucionario liderado por el coronel Marmaduke Grove, quien proclamó una "República Socialista" (Halperin 403). A pesar de la normalización de la situación política con el triunfo electoral de Alessandri, en 1933, Huidobro denunciaba los aprisionamientos y persecuciones del nuevo gobierno, entre ellos, el de Ricardo Lachtam (hijo). Nuevamente se expresaba el entendimiento y la solidaridad relativa entre comunistas y socialistas, igualados frente a las represiones gubernamentales.

Por medio del manifiesto, el secretario general de la AEAR (Huidobro) pedía que la denuncia fuera replicada en los órganos de las Asociaciones de intelectuales revolucionarios de todos los países del mundo). Como ha consignado Patricio Lizama (2016), Huidobro era entonces un poeta consagrado, había publicado su primer manifiesto creacionista en Buenos Aires en 1916 y desde entonces contaba con un importante reconocimiento tanto del ambiente literario porteño como del parisino, donde en los años veinte había participado de las vanguardias poéticas. Luego de haber residido en distintas partes del mundo, en 1933 Huidobro regresó a Santiago de Chile, donde se contactó con grupos artísticos locales, principalmente juveniles y también vanguardistas como los “decembristas" y el grupo Mandrágora (Crispiani 40-82), entre otros, al tiempo que buscó establecer una relación con el comunismo chileno.

Huidobro era miembro de la AEAR francesa y de la chilena a la vez. El entonces dirigente juvenil comunista, Volodia Teitelboim, recibió con entusiasmo al consagrado poeta y a sus propuestas de conjugar el arte con la revolución. No obstante, otro grupo de escritores comunistas chilenos resultó reticente a las intervenciones de Huidobro. Quien lo enfrentó con mayor énfasis fue Pablo de Rokha, poeta que, como ya se ha mencionado, firmó su adhesión al Congreso antiguerrero de Montevideo como representante del Comité Unido de las organizaciones artísticas de Chile.

La polémica, analizada en profundidad por Faride Zerán (2005), se inició en torno a Antología de poesía chilena nueva, compilada por los jóvenes Volodia 
Teitelboim y Eduardo Anguita, en la que participaban Huidobro, De Rokha y Neruda, junto a otros poetas. En las páginas del diario chileno La Opinión se produjeron fuertes cruces entre Pablo de Rokha, Vicente Huidobro y Pablo Neruda. Aquella "obligación de polemizar", a la que se refirió Beatriz Sarlo (1997) al estudiar la revista Contra, se encarnó con fuerza entre las figuras poéticas chilenas.

Disgustado por el lugar que le había tocado en la Antología, Pablo de Rokha llamó a Volodia Teitelboim "monaguillo y paniaguado del Pontífice [Huidobro]" (De Rokha, "Marginal a la Antología"). También afirmó que Huidobro era un "insidioso confusionista", y sostuvo:

“... yo no he pensado jamás que tú [Huidobro], a quien yo estudio, accidentalmente, como caso de pequeño-gran burgués megalómano, hubieses hecho fabricar la "Antología" por enemistad para quien esto escribe, solamente, sino por oportunismo, rotunda y desenfadadamente por oportunismo de arribista literario, que aprovecha y especula con los adolescentes, a los cuales tú declaras que acoges con los brazos abiertos (...) no voy a continuar golpeándote; me da flojera y asco, Vicentillo (...) pero si toda tu obra es mentira y es calumnia y "plagio" literatura de compra venta, ¡oh!, mistificador imprudente" (De Rokha,Carta al poeta).

Pablo de Rokha se consideraba a sí mismo un "proletario de la cultura", obrero de la técnica artística, que sufría las explotaciones del sistema capitalista, al igual que cualquier otro trabajador. Sus impugnaciones a los poetas rivales estuvieron asociadas a sus condiciones de vida "burguesas". De Rokha se refirió a Huidobro como parte de los "gandules que viven en la plusvalía, bisnietos de los encomenderos de la Corona"; y sobre Neruda afirmó: "Pablo Neruda entona la palinodia del versito surrealista, viste bien, come bien, duerme bien, y todos los primeros se va a incautar sus buenos pesos, emanados de la Tesorería General de la República" (De Rokha, Pablo Neruda). En cambio, recordaba su propio origen humilde, proveniente de una familia formada por diecinueve hermanos, cuyo padre fue un trabajador de un puesto aduanero cordillerano, y que su madre tenía catorce años cuando él había nacido.

Al describir su postura política, De Rokha aludía a sus propias limitaciones y virtudes: "Yo no pretendo servir aun a la revolución proletaria con toda la grandeza y el heroísmo necesario. Pero hay personas que me saben sincero y honrado, aun entre tus amigos, por ejemplo, Volodia Teitelboim" (De Rokha "Carta al poeta..."). En esa querella con Huidobro saludó al destinatario de sus críticas "con la hoz y el martillo". Huidobro le respondió y aludió a ese uso de esos símbolos: 
"Y por favor no hables de tu pobreza para probar tus ideas, ni nos cuentes que te ganas la comida para tus hijos a patadas con el ambiente o a patadas con tus amigos, nada de eso prueba nada. Hay obreros auténticamente pobres y que son reaccionarios y ha habido muchos hijos de padres ricos que han sido sinceros revolucionarios. Pero sobre todo no apeles para defender tus bajas pasiones a la hoz y al martillo. Son símbolos demasiado sagrados para mancharlos (Huidobro,Respuesta a la carta).

Como afirma Carine Dalmás (2013), las polémicas en el ambiente literario chileno incluyeron también a la escritora y periodista Marta Vergara, quien definió una forma específica de vinculación entre los escritores y los obreros: de acuerdo con Vergara, en tanto que el escritor pertenecía a una formación burguesa, debía someterse al liderazgo proletario. En este mismo sentido se orientó el artículo con características de manifiesto que firmaron en conjunto Marta Vergara, Pablo de Rokha, Gerardo Seguel, Carlos Poblete, Marcos Vega y Luis Luksic, titulado "Huidobro contra Neruda". El artículo se publicó por el periódico comunista chileno Frente único. Allí el grupo entonces más cercano al PC de escritores chilenos, afirmó que debido a que estaban en tiempos de agudización de la crisis del capitalismo, eran comprensibles las luchas entre escritores burgueses por plagios y por cuestiones de técnicas y frases (se referían a la acusación que Huidobro le hizo a Neruda de plagiar un poema de Rabindranath Tagore), pero que ellos, como grupo, se definían por oposición tanto a Huidobro como a Neruda:

"Pelearemos a cada hora y a cada minuto por hacer una literatura de combate con las nuevas ideas y los nuevos sentimientos de la revolución obrera y campesina. Dejamos a Huidobro y Neruda sus luchas por las frases ingeniosas y la técnica estéril (...). Muchos creen que Huidobro es un escritor revolucionario. No lo es todavía. Su obra 'revolucionaria' no va más allá de ciertas declaraciones. Nosotros, en cambio, creemos que no es posible practicar un arte revolucionario, sino impregnándose de la vida del proletariado, participando en los combates de clase que las masas libran bajo la dirección de la Internacional Comunista. Sin embargo, Huidobro tampoco tiene lazos con la reacción como Neruda y otros (...) si bien entre nosotros y Huidobro hay todavía, en los hechos, grandes diferencias, entre nosotros y Neruda, así como toda su corte aspirante a diplomáticos o policías, hay un abismo por medio: ellos ya se han colocado abiertamente en el campo de nuestros verdugos" (Vergara et al). 
Para el grupo que escribió este manifiesto colectivo, en comparación, Huidobro tenía mayor potencial revolucionario que Neruda, a quien veían como a un enemigo, en gran medida debido a que formaba parte del cuerpo diplomático del gobierno de Alessandri. Neruda además fue criticado por De Rokha por las características de su poesía "a la moda", en especial por el romanticismo de sus Veinte poemas de amor y una canción desesperada (1924), versos a los que se refirió como "sonsonete doliente e inicuo", "verso bobo", al que relacionaba con una "flojera interna y superflua"; en sus artículos "Epitafio a Neruda" (1933) y "Pablo Neruda plagiario o gran poeta" (1934) De Rokha aseguró también que Volodia Teitelboim había descubierto plagios de Neruda a Tagore, Huidobro y Humberto Díaz Casanueva, y que, si bien Federico García Lorca había halagado a Neruda, esta opinión carecía de valor porque el español era un poeta "de poca categoría". Por contraste, De Rokha definió su propia poesía como una herramienta al servicio del proletariado. Como se ha dicho ya, De Rokha se consideraba un obrero de la literatura y un escritor proletario (Dalmás 72-79). De acuerdo con el propio poeta, su tarea era proveer al proletariado de banderas e himnos de combate, consignas, cantos de guerra, apóstrofes.

Las críticas públicas a Neruda se interrumpieron cuando éste perdió su puesto de cónsul chileno en Madrid en medio de los acontecimientos de la Guerra Civil española (posición que recuperó al iniciarse el gobierno de Aguirre Cerda) y con el asesinato de García Lorca. El alejamiento de su cargo diplomático se produjo a la vez que Neruda explicitó su apoyo a grupos republicanos, y fomentó su relación con los poetas españoles republicanos, especialmente con García Lorca, a quien había conocido en Buenos Aires. Esa amistad le había abierto la puerta a un vínculo con otros poetas españoles como Rafael Alberti y Miguel Hernández, a quienes Neruda publicó en la revista Caballo Verde.

Las penurias de la Guerra Civil en España generaron las condiciones para una reconciliación entre los mencionados poetas chilenos, que, por el reconocimiento nacional e internacional con el que contaban, podían considerarse un grupo. De ese modo, publicaron juntos Madre España: homenaje de los poetas chilenos (1937), poemario organizado por Gerardo Seguel. Así, Vicente Huidobro, Pablo De Rokha, Pablo Neruda, Volodia Teitelboim, Blanca Luz Brum (de Uruguay), Rosamel del Valle y Winett De Rokha, entre otros, se unieron para participar de este homenaje, deponiendo sus antiguas rivalidades con vistas a defender una de las causas que más movilizó a los comunistas de Sudamérica.

Luego de haber residido en Madrid y París y de haber participado en el II Congreso de escritores antifascistas, Neruda regresó a Chile en 1937 junto a su pareja, la argentina Delia del Carril, y sus amigos también argentinos Amparo Mom y Raúl González Tuñón. Ese año se fundó en Santiago la Alianza de los 
Intelectuales de Chile en Defensa de la Cultura, en cuyo acto inaugural Neruda y Tuñón fueron los principales conferencistas. El discurso de Tuñón defendió el "cambio en la poesía" de Neruda:

“... - aunque no nos interesen los mezquinos, los cobardes, los reaccionarios - digamos a quienes han comentado por ahí con sorpresa - con miedo, con resentimiento - el libro de Pablo Neruda [España en el corazón] puede hacer poesía revolucionaria porque es un gran poeta, nada menos que uno de los más grandes poetas de nuestro tiempo" (González 37).

Como apunta Naím Nómez (1987) en el prólogo de la antología del poeta, ese mismo año Pablo De Rokha fue electo presidente de Casa América, órgano cultural del comunismo chileno, desde donde apoyó la conformación del Frente Popular. De acuerdo con su biógrafo Nómez (2010), si bien De Rokha fue candidato a diputado por el PC chileno, hacia 1938 entró en conflicto con el ámbito comunista y se alejó de las filas partidarias. Según lo relatado por Olga Ulianova (2008), también Marta Vergara y su esposo Marcos Chamudes, quienes habían sido figuras centrales del comunismo chileno, se alejaron del partido en medio de un desentendimiento con el delegado de la IC, el peruano Eudocio Ravines.

Neruda, en cambio, no estaba afiliado al PC chileno cuando promovió la Alianza de los Intelectuales de Chile, sino que era un "compañero de ruta" que se solidarizaba con la causa republicana española y se acercaba a las acciones y figuras partidarias comunistas. Como se ha señalado, la figura del compañero de ruta resultó fundamental en la conformación de organizaciones legales en las que se interactuó con el resto del campo cultural nacional. También resultó clave el rol del escritor comunista quien articuló las actividades culturales de Neruda con las del PC chileno. En este caso, Gerardo Seguel (1940) tomó esa tarea, fue el organizador y director de la revista Aurora de Chile, el diario El Siglo en 1940 y también fomentó la interacción entre la Alianza de los Intelectuales y la editorial Ercilla, que publicó sus libros. Mientras que Neruda y Tuñón aportaban sus prestigios como poetas, y traían a Sudamérica las experiencias europeas, por detrás, Gerardo Seguel se encargó de la organización de las publicaciones y actividades, en especial, porque pronto Neruda fue nombrado cónsul chileno en México y nuevamente dejó el país transandino.

El escritor y poeta Gerardo Seguel fue co-director de la Alianza de los Intelectuales, cargo que compartió con Neruda, Alberto Aldunate, Alberto Romero y Juan Negro. Desde esa posición y desde las distintas publicaciones 
vinculadas con la Alianza se encargó, por ejemplo, de defender a figuras como el poeta argentino Raúl González Tuñón cuando éste fue acusado de malversación de fondos destinados a los refugiados españoles. Asimismo, Seguel se ocupó de señalar uno de los tópicos que crecientemente "definía" a los comunistas: el anti-trotskismo. De acuerdo con Seguel, aquellos que no habían apoyado la conformación del Frente Popular y la candidatura de Aguirre Cerda, habían estado, en cambio, dispuestos a organizar un homenaje a Trotsky, quien había sido asesinado en México en agosto de 1940. Seguel describió a Trotsky como un ex agente de la policía alemana, y en el periódico El Siglo justificó su asesinato atribuyéndoselo a "amos anteriores".

Para Seguel, como para otros comunistas, Trotsky era un enemigo, especialmente problemático por haber sido cercano y formado parte del propio proceso revolucionario. En este sentido, las manifestaciones y acciones antitrotskistas resultaban una prueba de que se estaba ante un "verdadero" comunista. Así, Raúl González Tuñón publicó un artículo en las páginas de El Siglo a raíz de la muerte de Trostky, en el que demonizaba su figura ${ }^{6}$; David Siqueiros, cuya disciplina partidaria estaba en constante tensión desde su expulsión en 1930, participó en un atentado contra la vida de Trotsky; y también Pablo Neruda fortaleció su posición dentro del comunismo al proteger, desde su puesto consular en México, a Siqueiros luego de que éste acometiera a balazos contra la residencia de Trotsky. Al respecto, Neruda recordó años después:

"David Alfaro Siqueiros estaba entonces en la cárcel. Alguien lo había embarcado en una incursión armada a la casa de Trotsky. Lo conocí en la prisión (...) tramamos Siqueiros y yo su liberación definitiva. Provisto de una visa que yo mismo estampé en su pasaporte, se dirigió a Chile con su mujer, Angélica Arenales. México había construido una escuela en la ciudad de Chillán, que había sido destruida por los terremotos y en esa "Escuela México" Siqueiros pintó uno de sus murales extraordinarios. El gobierno de Chile me pagó este servicio a la cultura nacional, suspendiéndome de mis funciones de cónsul por dos meses" (Neruda, Confieso que he vivido 189-191).

6 “En Coyoacán, palacete campestre pagado por el dinero norteamericano, ha muerto León Trotzky, literato de nota, hombre pequeño y traidor del Partido Comunista y de la Unión Soviética. Nunca fue antifascista como nosotros lo fuimos - y lo somos-", González Tuñón, Raúl. "Sobre el cadáver de León Trotsky”. El Siglo, 4 de septiembre de 1940 
Neruda comenzó a ser apodado "el caudillo", mientras Seguel se encargó de fortalecer la organización de la Alianza de los intelectuales y las publicaciones afines, resaltando siempre el nombre y el itinerario de Neruda. Como contrapartida Neruda describió el desempeño intelectual de Seguel en los siguientes términos: "Seguel vive la vida iluminando la obra y la vida de los demás, limpiando y haciendo fulgurar la flora colectiva, encendiendo las lámparas antiguas con su valiente corazón patriota y comunista" (Neruda en Seguel 12). Para Olga Ulianova (2008) la Guerra Civil había iniciado un proceso de creciente consolidación de Neruda como referente cultural comunista en Chile y en la región, que se completó gracias a su rol en la Alianza de los Intelectuales, y por el espacio que dejaba libre el "tormentoso" De Rokha, quien había generado varios conflictos dentro del partido.

Por su parte, Neruda pudo desempeñar tal rol gracias a que Seguel, comunista "con carnet", se ocupaba de las tareas locales cuando el poeta se encontraba en el exterior. En consonancia con el triunfo del Frente Popular en Chile, Neruda podía establecer una tarea cultural "amplia" e "internacional". A la vez, buscó consolidarse en el espacio nacional comunista chileno, para lo cual, entre otras cosas, incorporó temáticas políticas y un tono combativo; inspiración política que, desde España en el corazón (1937) hasta Canto General, puede observarse en su obra.

La centralidad de Neruda se consolidó al ser electo senador nacional en 1945. Año en el que también fue asesor de campaña del entonces candidato a presidente Gabriel González Videla. 1945 fue un año de gran efervescencia para el comunismo a nivel mundial, y fue entonces cuando Neruda se afilió formalmente al PC chileno. Desde su triunfo electoral no hubo sitio para las críticas públicas ni las rivalidades con el resto de los artistas e intelectuales chilenos. Sin embargo, las rencillas se mantuvieron durante décadas, hasta el fin de las vidas de sus principales exponentes: Pablo De Rokha siguió siendo un crítico acérrimo de Neruda durante décadas; y, por su parte, Neruda mantuvo sus recelos respecto de Vicente Huidobro, fallecido en 1948, sobre quien rememoró la "vanidad" con la que se manejaba en el ambiente literario, en especial al recordar algunas anécdotas durante el transcurso del II Congreso de escritores antifascistas.

Neruda fue electo senador por la región de la pampa salitrera, Tarapacá y Antofagasta. Compartió entonces el recinto parlamentario con el conjunto del arco político, entre ellos dirigentes del comunismo y el socialismo chileno, como Elías Lafertte, Salvador Allende y Marmaduke Grove. En 1947 participó con alocuciones en el "Honorable Senado" para relatar su visita a los obreros salitreros: 
“... acabo de hacer una corta pero intensa jira [sic] por la pampa salitrera (...) Tuve oportunidad de preocuparme en recoger los datos necesarios; he convivido con los obreros, he dormido en sus habitaciones, en estos días he visto el trabajo en la pampa, en las máquinas, trabajos que podrían citarse como ejemplos de los más duros realizados sobre la tierra. Sin embargo, los salarios apenas alcanzan a los obreros para cubrir los gastos de su alimentación y, naturalmente, no bastan para satisfacer ninguna necesidad de índole cultural, que son negadas a esos obreros, que viven aislados del resto del país por la inmensa soledad del desierto" (Boletín de Sesiones Extraordinarias 896-897).

Aun cuando en 1947 Neruda denunció públicamente a las empresas salitreras, defendió a los huelguistas y abominó que las empresas se manejaran como dominios, señoríos o reinos, cabe señalar que sus impresiones del vínculo con los obreros refieren a una persistente exterioridad respecto de la clase obrera. La distancia entre el poeta y los obreros salitreros se encuentra tanto en sus exposiciones ante el Senado en 1947 como, años más tarde, en sus escritos memoriales. En Confieso que he vivido, Neruda rememoró sobre el norte chileno: "Entrar en aquellas planicies, enfrentar aquellos arenales, es entrar en la luna" (Neruda, Confieso que he vivido 206); "Yo no entendía su idioma, es decir, su silencio" (207). Esta descripción, posterior a la narración de sus cuantiosos viajes y residencias en lugares "exóticos" como Ceilán, India o China, profundiza la sensación de que para Neruda el norte salitrero era un espacio de alteridad.

Neruda dejó en claro que, a diferencia del "escritor proletario" De Rokha y el "escritor revolucionario" Huidobro, él era un poeta que "pensaba en" los obreros, que los acompañaba al escuchar sus silencios. Neruda narró un recuerdo agradecido hacia "esta gente sin escuela y sin zapatos" que lo había elegido senador de la República. Pero tanto en sus alocuciones en el Senado como en sus memorias, la pampa salitrera se encuentra lejana. Él no provenía de esas tierras, su infancia había transcurrido en "tierras verdes" al otro extremo de la República, y su vida en ciudades, entre las que Buenos Aires, París, Madrid eran sus favoritas. Por otro lado, su vida en Chile se había dividido entre su refugio en Isla Negra y su residencia en la casa "Michoacán" en el barrio La reina de Santiago. En esa casa se encuentra una amplia biblioteca, un estudio y un anfiteatro emplazado en el parque, ámbito de trabajo y de vida de Neruda y su pareja Delia del Carril. Allí vivió la pareja hasta que en 1947 el poeta emprendió un nuevo exilio, a raíz de su enfrentamiento con el presidente Gabriel González Videla. Neruda llamó entonces al presidente "Judas chileno" debido a que tomó 
medidas represivas contra el comunismo, enmarcadas en el avance del clima de Guerra Fría en la región, que quedaron fijadas en la llamada Ley de Defensa a la Democracia o Ley Maldita, que reprimía las actividades de los comunistas.

Neruda reunía todas las condiciones del artista-intelectual comunista en el Cono Sur: amistades y rivalidades, acciones regionales e internacionales, participación en organizaciones intelectuales, viajes, y, ya en los años cincuenta, alguna experiencia en la prisión. Asimismo, en sus memorias está presente la preocupación por que no se lo recordara como un "burgués" debido a su patrimonio en inmuebles; en este sentido, abundan explicaciones sobre los orígenes de sus bienes, entre ellos, la casa en Isla Negra y la casa "Michoacán".

Luego de pasar a la clandestinidad y exiliarse, Neruda volvió a colocarse en un estrato internacional y fue reconocido por las autoridades soviéticas, por ejemplo, al ser premiado, junto con Jorge Amado y Nicolás Guillen, en el marco del Segundo Congreso de Escritores Soviéticos (1954). En esos años Pablo De Rokha retomó en Chile las críticas públicas sobre su colega. Esta vez en un libro, Neruda y yo (1975), De Rokha centró sus críticas, precisamente, en las condiciones de vida de Neruda y en su exterioridad respecto de los trabajadores:

"Reitero y planteo mi adhesión incondicional al Partido Comunista, al enjuiciar a Pablo Neruda, como enemigo de los trabajadores, escondido en su vanguardia. (...) Pablo Neruda no pretendió poner su nombre al servicio del Partido Comunista, pretendió poner el Partido Comunista al servicio de su nombre, y su nombre se lo engendró la burguesía imperialista" (De Rokha, Neruda y yo ${ }^{7}$ ).

Aun cuando para la URSS Neruda era uno de los referentes literarios latinoamericanos, en Chile se mantuvieron vivas confrontaciones y acusaciones públicas como la señalada por parte de De Rokha. Pervivieron las tensiones relativas, por un lado, a rivalidades basadas en aspectos literarios y profesionales; por otro, al tipo de vínculo con el partido; y, también, al modo en el que entendían su relación con el mundo obrero. Estas rencillas estuvieron basadas además en enfrentamientos personales que duraron incluso más allá de la muerte de los contrincantes. 


\section{CONCLUSIONES}

A lo largo de este artículo se buscó reconstruir diferentes aspectos de la relación entre intelectuales-artistas, sensibilidad obrerista y partidos comunistas. Muchas de las figuras analizadas encontraron en el "obrerismo" un atractivo asociado a su anticapitalismo y un rechazo a las costumbres burguesas, que tuvo tanto peso como el apoyo a los procesos soviéticos. Como se ha visto, se emprendieron distintas búsquedas para definir la identidad del "escritor proletario", del "trabajador intelectual", o los "defensores de la cultura". En todos los casos se encuentra una tensión y la vigilancia relativa a los límites entre la condición burguesa y la defensa o adhesión al proletariado. Esa vigilancia no provino única y verticalmente de la dirigencia partidaria comunista, sino que se estableció también entre los propios pares. Los escenarios analizados en el artículo buscaron dar una perspectiva de la compleja trama que cruzó tal politización.

Asimismo, se ha matizado la idea de que el VII Congreso de la IC de 1935 fue el principal motor que inició la adhesión de los intelectuales y artistas en la región, al poner en evidencia que dicha adhesión se remonta, en realidad, a un período previo. Desde luego, no es con un afán de meticulosidad en la periodización que se puntualiza en este aspecto, sino con el fin de señalar que el obrerismo y el antiguerrerismo fueron otros motivos, también centrales, por los cuales esos intelectuales-artistas se comprometieron políticamente adhiriendo a los espacios patrocinados por los PP.CC. Se postula, así, que la asociación del obrerismo con una completa cerrazón "sectaria" y "anti-intelectualista" impide presentar en su complejidad los motivos por los cuales se produjo la politización de los intelectuales y artistas ligada a esos espacios partidarios en el Cono Sur.

\section{REFERENCIAS BIBLIOGRÁFICAS}

Álvarez, Luis. Vicente Lombardo Toledano y los sindicatos de México y Estados Unidos. UNAM- Praxis, 1995.

AA.VV. Madre España: homenaje de los poetas chilenos. Panorama, 1937. Boletín de sesiones extraordinarias, 1946-1947. Talleres gráficos "La Nación”, 1948.

Camarero, Hernán. A la conquista de la clase obrera. Los comunistas y el mundo del trabajo en la Argentina 1920-1935. Siglo XXI, 2007. https://doi. $\operatorname{org} / 10.1163 / 156920611 \times 564752$ 
Camarero, Hernán. "El tercer período de la Comintern en versión criolla. Avatares de una orientación combativa y sectaria del Partido Comunista hacia el movimiento obrero argentino". A Contracorriente, vol. VII, no. 3, 2011. pp. 203-232. https://doi.org/10.4067/s0718-50492016000300005

Caute, David. Compañeros de viaje. Una posdata a la ilustración. Grijalbo, 1975. Crispiani, Alejandro. Objetos para trasformar el mundo. UNQ-Prometeo, 2011. Codovilla, Victorio. El movimiento revolucionario Latino Americano. Versiones de la primera Conferencia Comunista Latino Americana junio de 1929, SSA de la IC. Editado por la revista La Correspondencia Sudamericana, 1929. https://doi.org/10.5212/rlagg.v.6.i2.0003

"Comunicado oficial del Comité organizador". El Trabajador Latinoamericano, no. 51/52, Noviembre de 1932.

"Chile frente al Congreso de Montevideo". El Trabajador Latinoamericano, no. 53/54, Febrero-Marzo de 1933.

Dalmás, Carine. Frentismo cultural em prosa e verso: comparações, conexões e circulação de ideias entre comunistas brasileiros e chilenos (1935-1948). Tesis Universidad de São Paulo, 2012. https://doi.org/10.11606/t.8.2013. tde-28062013-124712

Dalmás, Carine. "Frentismo cultural dos comunistas no Chile e no Brasil", Projeto História, no. 47, agosto 2013. pp. 225-258.

"De la Unión de escritores proletarios." Revista Actualidad, no. 3, Junio 1932.

De Rokha, Pablo. "Pablo Neruda poeta a la moda", La opinión, 11 de noviembre de 1932.

De Rokha, Pablo. "Marginal a la antología", La opinión, 10 de junio de 1935.

De Rokha, Pablo. "Carta al poeta Vicente Huidobro". La opinión, 23 de junio de 1935.

De Rokha, Pablo. Neruda y yo. Multitud, 1955.

"El escritor revolucionario, en las garras de Leguía". El Trabajador Latinoamericano, no. 24, 25, Noviembre 1929.

"El Sindicato de Artistas Plásticos. Su creación traduce un estado social". Revista Actualidad, no. 1, Junio-Julio 1933.

"Figuras del movimiento obrero internacional: Alejandro Lozovsky." El Trabajador Latinoamericano, no. 30, 1930.

Fitzpatrick, Sheila. La revolución rusa, Siglo XXI, 2015.

Grez Toso, Sergio. Historia del comunismo en Chile, la era Recabarren (19121924), LOM, 2011. https://doi.org/10.4067/s0719-12432012000100009

"Frente al problema de la guerra. Manifiesto de los intelectuales uruguayos." Revista Actualidad económica, política y social, no. 12, Febrero 1933. 
González Tuñón, Raúl. “España en el corazón.”. Tierra, no. 5, 1937.

González Tuñón, Raúl. "Sobre el cadáver de León Trotsky". El Siglo, 4 de septiembre de 1940.

Groys, Boris. Obra de arte total Stalin. Pre-textos, 2008.

Halperin Donghi, Tulio, Historia contemporánea de América Latina. Alianza, 1994.

Huidobro, Vicente. "Manifiesto de los escritores revolucionarios chilenos". Contra, no. 4, Agosto 1933.

Huidobro, Vicente."Respuesta a la carta de Pablo de Rokha". La opinión, Julio 1935.

Jeifets, Lazar y Víctor Jeifets. Diccionario Biográfico América Latina en la Internacional Comunista 1919-1943. Ariadna, 2015. https://doi. org/10.26448/9789568416393.2

Judt, Tony. Past imperfect. French intellectuals, 1944-1956. New York University Press, 2011.

Lacquaniti, Leandro. "La Comisión Nacional de Cultura. Estado y política cultural en la Argentina". IV Jornadas "Política de masas y cultura de masas. América Latina en entreguerras", Universidad Nacional General Sarmiento, 2016. https://doi.org/10.19137/quintosol-2015-190304

"La Unión de escritores proletarios". Revista Actualidad, no. 2, Junio 1932.

Larra, Raúl. Etcétera. Ánfora, 1982.

"Las sesiones de la Conferencia Sindical Anti-Guerrera". El Trabajador Latinoamericano, no. 12/13/14, Febrero-Marzo 1929.

Lizama, Patricio. "Huidobro y la vanguardia de los años 30". Vicente Huidobro Universidad de Chile. Web. 15. Mar. 2016. http://www.vicentehuidobro. uchile.cl/ensayo_patricio_lizama.htm

Lombardo Toledano, Vicente. Los derechos sindicales de los trabajadores intelectuales (folleto). Editorial Cvlivra, 1927.

"Llamado de los intelectuales argentino a todos los intelectuales de América Latina." El Trabajador Latinoamericano, no. 53/54, Enero - Febrero 1933.

Mariátegui, José. "El problema del indio en el Perú". El Trabajador Latinoamericano, no. 9, Agosto 1929.

Mariátegui, José. "El problema indígena". El Trabajador Latinoamericano, no.19, Agosto 1929.

Marx, Karl. Obras escogidas. Tomo IV. Editorial ciencias del hombre, 1973.

Neruda, Pablo. España en el corazón. Himno a las glorias del pueblo en la guerra. Ercilla, 1937.

Neruda, Pablo. "Pedro de Oña y Seguel", en Seguel, Gerardo. Pedro de Oña. Ercilla, 1940. 
Neruda, Pablo. "Condiciones de trabajo de los obreros del salitre. Huelga en la oficina "Iris"'. Boletín de sesiones extraordinarias, 1946-1947. Talleres gráficos "La Nación”, 1948. pp. 896-897.

Neruda, Pablo. Confieso que he vivido. Seix Barral, 2004. http://doi.org/10.4067/ s0718-50492018000600299

Nómez, Naím. "Pablo de Rokha, vanguardia, utopía e identidad en la poesía chilena". Ómnibus, no. 30, 2010. Web. 16. Mar. 2016. https://doi. org/10.31819/9783964560131-021

Nómez, Naim. "Prólogo. Biografía del Amigo Piedra". Pablo de Rokha. Nueva antología. Editorial sin fronteras, 1987.

“Origen y desarrollo de los sindicatos de oficio." El Trabajador Latinoamericano, no. 3, Marzo-Abril 1928.

Pasolini, Ricardo. Los marxistas liberales. Antifascismo y cultura comunista en la Argentina del siglo XX. Sudamericana, 2013. https://doi.org/10.18294/ pm.2014.431

Ponce, Aníbal. "El primer año de AIAPE". Dialéctica, no. 6, Agosto de 1936.

Ponce, Aníbal. Obras Completas. Tomo I. Cartago, 1974.

Prado Acosta, Laura. Los intelectuales del Partido Comunista: itinerario de Héctor Agosti (1930-1963). A Contracorriente, 2015. https://doi. org/10.1017/s0022216x17000608

Rossi, Cristina. "Impacto del discurso siqueriano sobre el gremio de los artistas plásticos argentinos". Actas II Jornadas de historia de las izquierdas. Cedinci, 2002.

SAAP. "Historia". Sociedad Argentina de Artistas Plásticos. Web. 20. May. 2016. http://www.saap.com.ar/historia/01-35-45.htm.

Sarlo, Beatriz. Una modernidad periférica: Buenos Aires 1920 y 1930. Nueva Visión, 2007. https://doi.org/10.1353/ntc.1989.0021

Seguel, Gerardo. "El trotskysmo y la ayuda chilena a la república española". El Siglo, 8 de septiembre de 1940.

Siqueiros, David. "La lucha contra el imperialismo y la CSLA". Bajo la bandera de la C.S.L.A., resoluciones y documentos varios del Congreso Constituyente de la Confederación Sindical Latino Americana efectuado en Montevideo en Mayo de 1929. Confederación Sindical Latino Americana (Uruguay). Imprenta La Linotipo, 1929, pp. 210-222,

Tamayo, Jaime. "Siqueiros, los orígenes del movimiento rojo en Jalisco y el movimiento minero". Centro de Investigaciones Históricas. Instituto de Investigaciones Humanísticas, Anuario III, Universidad Veracruzana, 1981.

Tarcus, Horacio. Mariátegui en la Argentina y las políticas culturales de Samuel Glusberg. El cielo por asalto, 2002. 
Ulianova, Olga. "Develando un mito: emisarios de la internacional comunista en Chile". Historia, vol. 1, no. 41, 2008, pp. 99-164. https://repositorio. uc.cl/handle/11534/9833

"Unión de escritores proletarios". Revista Actualidad, no. 4, Julio 1932.

Utley, Gertje. Pablo Picasso: the communist years. Yale University Press, 2000. Verdès Leroux, Jeannine. Au service du Parti. Le parti communiste, les intellectuels et la culture (1944-1956). Fayard, 1983.

Vergara, Marta, et al. "Huidobro contra Neruda". Frente único, no. 3, enero 1935.

Zerán, Faride. La guerrilla literaria. Fondo de Cultura Económica, 2005.

Agradecimientos: Agradezco a Miguel Ramos Toro de la Biblioteca del Congreso Nacional de Chile por su amabilidad en el acceso a los materiales de archivo. 